\title{
BIOLOGICAL STUDIES ON THE MEALYBUG Maconellicoccus hirsutus (GREEN)(HEMIPTERA: PSEUDOCOCCIDAE) REARED ON POTATO SPROUT TUBERS UNDER LABORATORY CONDITIONS.
}

Osman, Evon A.

Plant Protection Research Institute Agricultur Res. Cent.Dokki GizaEgypt

\begin{abstract}
This study was suggested to determine some biological aspects of this insect pest under laboratory conditions on potato sprout tubers. Obtained results can be summarizes as follows: The first, second and third nymphal instars lasted for 8-14, 716 and 10-19 days, respectively according to generation. Pre-ovipostion, oviposition and post-oviposition periods were 11-21, 49-67 and 6-15 days, respectively. Oviposition periods greatly influenced with prevailing laboratory temperature and humidity. Pre-oviposition, oviposition and post-oviposition periods were positively affected with temperature in the first second and third generations for each of period. Highest fecundity per female recorded in the first generation whereas lowest one took place in the third generation. The longest longevity average occurred in third generation followed by that in the second generation. Whereas lowest one took place in the first generation. Incubation period averages were in the first, second and third generations lasted for 3-12, 10-31 and 30-45 days, respectively. Total life cycle completed in 94-164 days in first generation, 110-234 in second generation and 207399 days in third generation
\end{abstract}

Keywords: Biological studies, mealy bug, M. hirsutus and sprouting Potato ubers.

\section{INTRODUCTION}

Maconellicoccus hirsutus (Green)(Hemiptera: Pseudococcidae) is a polyphagous insect pest which feeds on a wide range of important species including hibiscus, citrus, coffee, sugar cane, annonas, plums, guava, mango, okra, sorrel, teak, mora, pigeon pea, peanut, grape, maize, asparagus, chrysanthemum, beans, cotton, soybean, rose, and other fiber crops just to name a few of its hosts. Host plants extend to 76 families and over 200 genera.(Ranjan, 2006; Ujjan \& Shahzad, 2007; Reddy et al., 2009). The feeding of $M$. hirsutus causes malformation of shoots and leaves believed to be caused by the injection of a toxic saliva (Kairo et al., 2000). In addition to lowering the aesthetics of the plant, this deformation can also result in lowered crop yields and in heavy infestations, plant mortality (Kairo et al., 2000 and Chong et al. 2008). Like other sap sucking insects, M. hirsutus also excretes a sugary honeydew on which sooty mold develops, further deteriorating the quality of the agricultural or forest product (Gonzalez-Gaona et al., 2010). The presence of large quantities of wax, characteristic of $M$. hirsutus infestations, also reduces the aesthetic and commercial value of ornamentals (Kairo et al., 2000).

The pink hibiscus mealybug is a serious economic threat to agriculture, forestry, and the nursery industry. As it feeds, using a piercing and sucking process, the pink hibiscus mealybug injects into the plant a toxic 


\section{Osman, Evon A.}

saliva that results in malformed leaf and shoot growth, stunting and occasionally death. Leaves show a characteristic curling, similar to damage caused by viruses. Heavily infested plants have shortened internodes leading to a "bunchy top" appearance. A heavy black sooty mold may develop on an infested plant's leaves and stems as a result of the mealybug's heavy honeydew secretions. When fruits are infested, they can be entirely covered with the white waxy coating of the mealybug. Infestation can lead to fruit drop, or fruit may remain on the host in a dried and shriveled the studies condition. If flower blossoms are attacked, the fruit sets poorly. reported the presented study aimed to explore some biological aspects of $M$. hirsutus under laboratory conditions throughout summer, autumn, winter and spring seasons to evaluate the effect of potato sprout tubers on the initial life history of $M$. hirsutus

\section{MATERIALS AND METHODS}

Experiments were conducted under laboratory conditions located at Plant Protection Research Institute (ARC), Dokki, Giza Governorate throughout mid May 2009 till late at day- maximum temperature average $37.7 \pm 0.9^{\circ} \mathrm{C}$, and night minimum temperature average $25.1 \pm 0.2^{\circ} \mathrm{C}$ and the daily mean relative humidity ranged $44.5-54.5 \%$. Potato sprouts were used in rearing of the pink hibiscus mealy bug, $M$. hirsutus. Tubers were kept in isolation from any insect infestation using a carto cylindrical box of $8 \mathrm{~cm}$ long and $12 \mathrm{~cm}$ diameter.

\section{1-Insect Source :}

In order to have a good supply of pink hibiscus mealy bug a colony was made available for different aspects of the work and maintained under a routine rearing method in the lab. Reproducing scales obtained from different field at different periods were allowed to settle on potato sprouts by collecting leaves and branches of Hibiscus tiliaceus (Malvaceae) trees heavily infested of $M$. hirsutus, carefully separated under a stereomicroscope .

\section{2-Rearing:}

To infest potato sprouts tuber in the lab. five newly hatched nymphs (crawlers) were transferred carefully to each clean tuber using a fine moistened camel's hair brush $(5 \%)$. The sprouting potato tubers were observed every 24 hours until the crawlers settled on different tuber. Dead crawlers were replaced with newly hatched ones. Only one crawler was allawed on each tuber. The location of each crawler was marked with a circle using indelible ink.

Daily inspection of infested potato sprouts were made and all until producing another progeny. Records were taken for each crawler to record the durations of the three nymphal stages. The prevailing laboratory daymax.temp., night-min. temp. and daily mean relative humidity were daily recorded.

To evaluate the pre-oviposition, oviposition and post-oviposition periods, a ten potato sprouts were used and kept each in a suitable carton cylindrical box of $8 \mathrm{~cm}$ long and $12 \mathrm{~cm}$ diameter. Newly emerging females 
(one/ potato sprouts) were transferred carefully the potato sprouts were daily inspected, until insects settled on the potato sprouts, then daily observed to obtain the pre-oviposition, oviposition and post-oviposition periods as well as fecundity and adult longevity .

Fecundity of female was calculated as the sum of deposited and undeposited eggs. Undeposited eggs were counted by dissecting dead mature females under the stereoscopicbinocular.The incubation period was determind as the period between the deposition of the first egg and the emergence of the first crawler.This period was estimated by inspecting 20 individual eggs deposited in female egg sac with the aid of a stereomicroscope. Twice a day for newly hatched crawler. After mother scale forming egg sac, the egg sac was inspected to follow up eggs production. The generation period was also estimated.

\section{3- Statistical analysis:}

Obtained data were subject to statistical analysis using the (ANOVA) and the Duncan's multiple range as described by Snedecor (1970).

\section{RESULTS AND DISCUSSION}

\section{1-Duration of the nymphal stage:}

The durations of the three nymphal instars during the three successive annual generations under prevailing laboratory conditions are presented in Table (1).The $1^{\text {st }}, 2^{\text {nd }}$ and $3^{\text {rd }}$ instars lasted for 8-14, 7-16 and 10-19 days, respectively, in the first generation; $5-12,6-15$ and 8-18 days, in the second generation and 14-30, 14-33 and 24-36 days in the third generation. The shorter durations occurred during the second generation $(8.8 \pm 0.56,10.25 \pm 0.75$ and $13.8 \pm 0.83))$ as compared with to the first one with $(11.45 \pm 0.39,11.15 \pm 0.48$ and $14.65 \pm 0.81)$ average and the third generation with $(20.9 \pm 1.17,21.25 \pm 1.39$ and29.7 \pm 0.72$)$. The total nymphal period (from egg hatching until adult emergence) was $37.25 \pm 0.91$ days in the $1^{\text {st }}$ generation, $32.8 \pm 1.21$ days in the $2^{\text {nd }}$ generation and $71.8 \pm 2.34$ days in the $3^{\text {rd }}$ generation. Significant differences were attained between duration periods of nymphal instars and between generations. Nymphs reared on potato sprouts during the first generations at $34.1 \pm 0.25{ }^{\circ} \mathrm{C}$ (D. Max. T), $32.9 \pm 0.23{ }^{\circ} \mathrm{C}$ as well as $50.5 \pm 0.77 \%$ (D. M. R. H.) developed to adult females significantly faster than those reared at $28.3 \pm 0.78{ }^{\circ} \mathrm{C}$ (D. Max. T), $27.1 \pm 0.75{ }^{\circ} \mathrm{C}$ and $51.6 \pm 0.05 \%$ (D. M. R. H.). The mean developmental period for nymphal instars and thus nymphal stage were inversely proportional with the increas in temperature. For instance, when the nymphal stage duration was shorter $\left(32.8 \pm 1.21\right.$ days) during $2^{\text {nd }}$ generation, the daily mean temp. was high $\left(34.6{ }^{\circ} \mathrm{C}\right)$ in comparison with the respective period during the first and third generation. These results were compairable with those by several authors on Icerya purchasi Kuwana(Hemiptera: Margarodidea) (1922) in Japan stated that the durations of different nymphal instars lasted $14-21,14-21$ and $12-50$ days for $1^{\text {st }}, 2^{\text {nd }}$, and $3^{\text {rd }}$ nymphal instars, respectively; Bodenheimer (1951) in Palestine 12-19, 40- 18 and 1124 days in the three nymphal instars, respectively; Monastero and Zaazmi 


\section{Osman, Evon A.}

(1959) in France stated that the three instars were 22-45, 15-25 and 35-37 days respectively. On the other hand, Ezz (1965) in Egypt found that three nymphal instars of Icerya aegyptiaca (Doulgas) (Hemiptera: Margarodidea)ranged 10-46, 7-30 days and 10-48 days; Azab et al (1969) in Egypt recorded 19, 9.8 and 20.7 days, respectively for three nymphal instars of Icerya aegyptiaca. Sharaf El-Den ,et al (2009) in Egypt found that three nymphal instars of Icerya seychellarum. (Hemiptera: Margarodidea) Such differences in results may be due to prevailing laboratory conditions, differences in insect species and host plants.

Table (1): Durations of $M$. hirsutue nymphal instars on Potato sprouts during the three successive annual generations under laboratory conditions.

\begin{tabular}{|c|c|c|c|c|c|}
\hline \multicolumn{6}{|c|}{ Duration of nymphal instars } \\
\hline $\begin{array}{l}\text { No. of } \\
\text { G. }\end{array}$ & $\begin{array}{c}\text { No. of } \\
\text { parameters }\end{array}$ & $1^{\text {st }} \mathrm{N}$. instar & $2^{\text {nd }} N$. instar & $3^{\text {rd }}$ N. instar & $\begin{array}{l}\text { Total N. } \\
\text { instar }\end{array}$ \\
\hline \multirow{6}{*}{ क๘ } & Range & $8-14$ & $7-16$ & $10-19$ & $25-49$ \\
\hline & $\begin{array}{l}\text { Mean } \\
\text { S.E }\end{array}$ & $\begin{array}{c}11.45 b \\
\pm 0.39\end{array}$ & $\begin{array}{c}11.15 b \\
\pm 0.48\end{array}$ & $\begin{array}{c}14.65 \mathbf{b} \\
\pm 0.81\end{array}$ & $\begin{array}{c}37.25 b \\
\pm 0.91\end{array}$ \\
\hline & Date & $12-5 / 3-6$ & $28-5 / 14-6$ & $12-6 / 26-6$ & $12-5 / 26-6$ \\
\hline & Tem/Max. & $34.1 \pm 0.12$ & $34.7 \pm 0.20$ & $33.6 \pm 0.13$ & $34.1 \pm 0.25$ \\
\hline & Tem/Mini. & $32.7 \pm 0.12$ & $33.5 \pm 0.11$ & $32.6 \pm 0.12$ & $32.9 \pm 0.23$ \\
\hline & $\mathrm{RH} \%$ & $48.9 \pm 0.34$ & $52.2 \pm 0.79$ & $50.5 \pm 1.02$ & $50.5 \pm 0.77$ \\
\hline \multirow{6}{*}{ 든 $\frac{\frac{c}{0}}{\frac{0}{\pi}}$} & Range & $5-12$ & $6-15$ & $8-18$ & $19-45$ \\
\hline & $\begin{array}{l}\text { Mean } \\
\text { S.E }\end{array}$ & $8.8 \pm 0.56 c$ & $10.25 \pm 0.75 c$ & $13.8 \pm 0.83 c$ & $32.8 \pm 1.21 \mathrm{c}$ \\
\hline & Date & $1-7 / 2-8$ & $10-7 / 15-8$ & $25-7 / 1-9$ & $1-7 / 1-9$ \\
\hline & Tem/Max. & $35.3 \pm 0.2$ & $34.9 \pm 0.21$ & $33.9 \pm 0.21$ & $34.7 \pm 0.33$ \\
\hline & Tem/Mini & $32.2 \pm 0.11$ & $32.3 \pm 0.11$ & $32.7 \pm 0.31$ & $34.4 \pm 0.12$ \\
\hline & $\mathrm{RH} \%$ & $51.6 \pm 0.45$ & $52.1 \pm 0.41$ & $53.2 \pm 0.21$ & $52.3 \pm 0.38$ \\
\hline \multirow{6}{*}{ 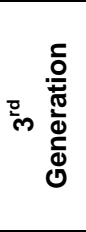 } & Range & $14-30$ & 14-33 & $24-36$ & $52-99$ \\
\hline & $\begin{array}{l}\text { Mean } \\
\text { S.E }\end{array}$ & $\begin{array}{l}20.9 \mathbf{a} \\
\pm 1.17\end{array}$ & $\begin{array}{c}21.25 a \\
\pm 1.39\end{array}$ & $\begin{array}{l}29.7 a \\
\pm 0.72\end{array}$ & $\begin{array}{l}71.8 \mathbf{a} \\
\pm 2.34\end{array}$ \\
\hline & Date & $23-8 / 8-11$ & $5-9 / 29-11$ & $20-9 / 6-1$ & $23-8 / 6-1 / 2010$ \\
\hline & Tem/Max. & $29.9 \pm 0.29$ & $28.9 \pm 0.28$ & $26.2 \pm 0.15$ & $28.3 \pm 0.78$ \\
\hline & Tem/Mini & $28.1 \pm 0.27$ & $28.0 \pm 0.27$ & $25.2 \pm 0.21$ & $27.1 \pm 0.75$ \\
\hline & $\mathrm{RH} \%$ & $51.7 \pm 1.41$ & $51.6 \pm 0.44$ & $51.8 \pm 0.61$ & $51.6 \pm 0.05$ \\
\hline
\end{tabular}

Initial numbers used for each nymphal instar were $\mathbf{2 0}$

Means within a column followed by different letter are significantly differ at $5 \%$.

\section{2- Duration of the pre-pupal and pupal stages}

The durations of the pre-pupal and pupal stages during the three successive annual generations under prevailing laboratory conditions are presented in Table (2). The pre-pupal and pupal stages lasted for 11-23 and 17-25 days, respectively,in the first generation, 8-17 and 9-18 days, in the second generation and 15-33 and17-37 days, in the third generation. The shorter durations occurred during the second generation $(12.4 \pm 0.69$ and $11.95 \pm 0.66)$ as compared with to the first one with $(15.85 \pm 0.57$ and $20.7 \pm 0.57)$ average and the third generation with $(25.45 \pm 1.46$ and 25.5 1.37).The total period (pre-pupal and pupal stages) was $18.27 \pm 1.71$ days in the $1^{\text {st }}$ generation, $12.17 \pm 0.16$ days in the $2^{\text {nd }}$ generation and $25.47 \pm 0.17$ days in the $3^{\text {rd }}$ generation. 
Table (2): Durations of $M$. hirsutus pupal, stage and reared potato sprouts during the three successive annual generations under laboratory conditions.

\begin{tabular}{|c|c|c|c|c|c|}
\hline $\begin{array}{c}\text { No. of } \\
\text { G. }\end{array}$ & $\begin{array}{c}\text { No. of } \\
\text { parameters }\end{array}$ & Pre pupae & Pupa & $\begin{array}{c}\text { Total pre-pupal } \\
\text { and pupal } \\
\text { stages }\end{array}$ & Adult Male \\
\hline \multirow{6}{*}{ r } & Range & $11-23$ & $17-25$ & $28-48$ & $1-6$ \\
\hline & $\begin{array}{l}\text { Mean } \\
\text { S.E }\end{array}$ & $\begin{array}{c}15.85 b \\
\pm 0.82\end{array}$ & $\begin{array}{l}\text { 20.7b } \\
\pm 0.57\end{array}$ & $18.27 \pm 1.71 b$ & $\begin{array}{c}3.2 \mathbf{a} \\
\pm 0.31 \\
\end{array}$ \\
\hline & Date & $8-6 / 1-7$ & 19-6/20-7 & $8-6 / 20-7$ & $8-7 / 21-7$ \\
\hline & Tem/Max. & $34.3 \pm 0.21$ & $34.3 \pm 0.31$ & $34.31 \pm 0.01$ & $35.1 \pm 0.42$ \\
\hline & Tem/Mini & $32.8 \pm 0.32$ & $32.9 \pm 0.42$ & $32.8 \pm 0.04$ & $33.9 \pm 0.51$ \\
\hline & $\mathrm{RH} \%$ & $49.9 \pm 0.41$ & $50.1 \pm 0.50$ & $50.0 \pm 0.07$ & $51.2 \pm 0.51$ \\
\hline \multirow{6}{*}{ م } & Range & $8-17$ & $9-18$ & $17-35$ & $1-4$ \\
\hline & $\begin{array}{l}\text { Mean } \\
\text { S.E }\end{array}$ & $\begin{array}{l}12.4 c \\
\pm 0.66\end{array}$ & $\begin{array}{c}11.95 \mathrm{c} \\
\pm 0.69\end{array}$ & $12.17 \pm 0.16 c$ & $\begin{array}{l}2.35 b \\
\pm 0.20\end{array}$ \\
\hline & Date & $25-7 / 31-8$ & $2-8 / 9-9$ & $25-7 / 9-9$ & $10-8 / 11-9$ \\
\hline & Tem/Max. & $35.2 \pm 0.41$ & $35.3 \pm 0.71$ & $35.3 \pm 0.04$ & $34.9 \pm 0.60$ \\
\hline & Tem/Mini & $33.1 \pm 0.60$ & $33.5 \pm 0.71$ & $33.3 \pm 0.14$ & $32.9 \pm 0.91$ \\
\hline & $\mathrm{RH} \%$ & $51.9 \pm 0.22$ & $52.3 \pm 0.41$ & $52.1 \pm 0.14$ & $53.3 \pm 0.33$ \\
\hline \multirow{6}{*}{$\frac{\frac{c}{0}}{\frac{\pi}{\pi}}$} & Range & $15-33$ & $17-37$ & $32-70$ & $1-3$ \\
\hline & $\begin{array}{l}\text { Mean } \\
\text { S.E }\end{array}$ & $\begin{array}{c}25.45 a \\
\pm 1.37\end{array}$ & $\begin{array}{r}25.5 \text { a } \\
\pm 1.46\end{array}$ & $25.47 \pm 0.17 a$ & $\begin{array}{c}1.9 c \\
\pm 0.18\end{array}$ \\
\hline & Date & $20-9 / 26-12$ & $4-10 / 14-2$ & $20-9 / 14-2$ & $20-10 / 14-2$ \\
\hline & Tem/Max. & $29.1 \pm 0.71$ & $28.9 \pm 0.31$ & $29.0 \pm 0.07$ & $27.5 \pm 0.51$ \\
\hline & Tem/Mini & 28. \pm 0.11 & $28.1 \pm 0.30$ & $28.05 \pm 0.35$ & $25.2 \pm 0.21$ \\
\hline & $\mathrm{RH} \%$ & $51.1 \pm 0.45$ & $51.6 \pm 0.45$ & $51.35 \pm 0.17$ & $51.9 \pm 0.71$ \\
\hline
\end{tabular}

Initial numbers used were 20 (adult females)

Means within a column followed by different letter are significantly differ at $5 \%$.

\section{3-Oviposition Periods \& Fecundity :}

Based on Table (3) the oviposition periods of $M$. hirsutus, during the three successive annual generations revealed the followings; the nonfertilized females started to lay eggs after their third molting. Statistical analysis showed that the pre- oviposition period was significantly different in generations tested, being less $16.9 \pm 0.67$ days in the $1^{\text {st }}$ generation at 33.33 ${ }^{\circ} \mathrm{C}$ and $50.1 \% \mathrm{R}$. $\mathrm{H}$. than that during the $2^{\text {nd }}$ generation $(20.25 \pm 0.66$ days) at $34.1{ }^{\circ} \mathrm{C}$ and $50.9 \% \mathrm{R}$. H. and the $3^{\text {rd }}$ generation $(51.65 \pm 1.96$ days $)$ at $28.9^{\circ} \mathrm{C}$ and $49.7 \% \mathrm{R}$. H. This period decreased with temperature increase.

Unfertilized females continued to lay eggs for 49-166 days. Significant differences were obtained in oviposition period between, generations, being shorter $\left(54.7 \pm 1.8\right.$ days) in the $1^{\text {st }}$ generation at $33.25^{\circ} \mathrm{C}$ and $50.2 \pm 0.21 \% R$. $\mathrm{H}$. while longer $\left(131.35 \pm 6.4\right.$ days) in the $3^{\text {rd }}$ generation at $27.65{ }^{\circ} \mathrm{C}$ and $49.2 \pm 0.21 \%$ R. H. Fecundity of females on potato sprouts ranged $79-201$ eggs per female in $1^{\text {st }}$ generation, 39 to 101 eggs/female in the $2^{\text {nd }}$ generation and $36-98$ eggs/female in the $3^{\text {rd }}$ generation. These differences were significant .The highest fecundity was recorded in the $1^{\text {st }}$ generation (117.1 \pm 9.59 eggs/female) . 
Table (3): Oviposition periods of $M$. hirsutus reared on potato sprouts during the three successive annual generations under laboratory conditions.

\begin{tabular}{|c|c|c|c|c|c|}
\hline 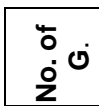 & $\begin{array}{c}\text { No. of } \\
\text { parameters }\end{array}$ & $\begin{array}{c}\text { Pre oviposition } \\
\text { periods }\end{array}$ & $\begin{array}{l}\text { oviposition } \\
\text { periods }\end{array}$ & $\begin{array}{l}\text { Total no. of } \\
\text { eggs / female } \\
\text { (Fecundity) }\end{array}$ & $\begin{array}{c}\text { post } \\
\text { oviposition } \\
\text { periods }\end{array}$ \\
\hline \multirow{4}{*}{ - $\frac{\frac{c}{0}}{\frac{0}{0}}$} & Range & $11-21$ & $49-67$ & $79-201$ & $6-15$ \\
\hline & $\begin{array}{l}\text { Mean } \\
\text { S.E }\end{array}$ & $\begin{array}{l}16.9 c \\
\pm 0.67\end{array}$ & $\begin{array}{c}54.75 c \\
\pm 0.61\end{array}$ & $\begin{array}{l}117.1 \mathrm{a} \\
\pm 9.59\end{array}$ & $\begin{array}{l}11.3 \mathbf{b} \\
\pm 0.58\end{array}$ \\
\hline & Date & $12-6 / 16-7$ & $22-6 / 23-7$ & $22-6 / 12-9-2009$ & $10-8 / 24-9$ \\
\hline & $\begin{array}{l}\text { Tem/Max. } \\
\text { Tem/Mini } \\
\text { RH\% }\end{array}$ & $\begin{array}{c}34.37 \pm 0.15 \\
32.3 \pm 0.13 \\
50.1 \pm 0.31\end{array}$ & $\begin{array}{l}34.4 \pm 0.61 \\
32.1 \pm 0.31 \\
50.2 \pm 0.21\end{array}$ & $\begin{array}{c}34.38 \pm 0.01 \\
32.2 \pm 0.07 \\
50.15 \pm 0.04\end{array}$ & $\begin{array}{l}35.3 \pm 0.11 \\
34.8 \pm 0.21 \\
50.4 \pm 0.45\end{array}$ \\
\hline \multirow{4}{*}{ ๙ } & Range & $13-27$ & 64-123 & $39-101$ & $4-8$ \\
\hline & $\begin{array}{l}\text { Mean } \\
\text { S.E }\end{array}$ & $\begin{array}{c}20.25 b \\
\pm 0.66\end{array}$ & $\begin{array}{c}87.05 b \\
\pm 0.69\end{array}$ & $\begin{array}{c}80.55 b \\
\pm \quad 4.7\end{array}$ & $\begin{array}{c}5.85 \quad \mathbf{c} \\
\pm 0.20\end{array}$ \\
\hline & Date & $1-8 / 27-9$ & $14-8 / 2-1$ & $14-8 / 2-1$ & $25-10 / 7-1$ \\
\hline & $\begin{array}{l}\text { Tem/Max. } \\
\text { Tem/Mini } \\
\text { RH\% } \%\end{array}$ & $\begin{array}{c}34.71 \pm 0.51 \\
33.4 \pm 0.60 \\
50.9 \pm 0.44\end{array}$ & $\begin{array}{l}33.9 \pm 0.71 \\
32.1 \pm 0.51 \\
49.9 \pm 0.17\end{array}$ & $\begin{array}{c}34.31 \pm 0.28 \\
32.7 \pm 0.45 \\
50.4 \pm 0.35\end{array}$ & $\begin{array}{l}33.7 \pm 0.72 \\
32.1 \pm 0.51 \\
50.0 \pm 0.12\end{array}$ \\
\hline \multirow{4}{*}{ 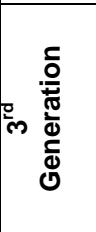 } & Range & $34-66$ & $78-166$ & $36-98$ & $13-23$ \\
\hline & $\begin{array}{l}\text { Mean } \\
\text { S.E }\end{array}$ & $\begin{array}{c}51.65 a \\
\pm 1.96\end{array}$ & $\begin{array}{c}131.35 a \\
\pm 6.48\end{array}$ & $\begin{array}{c}71.95 c \\
\pm 4.46\end{array}$ & $\begin{array}{l}17.0 \mathbf{a} \\
\pm 0.60 \\
\end{array}$ \\
\hline & Date & $17-10 / 11-2$ & $19-11 / 26-7$ & $19-11 / 26-7$ & $5-2 / 10-8$ \\
\hline & $\begin{array}{l}\text { Tem/Max. } \\
\text { Tem/Mini } \\
\text { RH\% }\end{array}$ & $\begin{array}{l}29.9 \pm 0.33 \\
27.9 \pm 0.51 \\
49.7 \pm 0.21\end{array}$ & $\begin{array}{l}28.1 \pm 0.12 \\
27.2 \pm 0.51 \\
49.2 \pm 0.21\end{array}$ & $\begin{array}{l}29.0 \pm 0.63 \\
27.6 \pm 0.24 \\
49.5 \pm 0.17\end{array}$ & $\begin{array}{l}26.5 \pm 0.31 \\
26.9 \pm 0.31 \\
49.9 \pm 0.21\end{array}$ \\
\hline
\end{tabular}

Initial numbers used were 20 (adult females)

Means within a column followed by different letter are significantly differ at $5 \%$.

The post-oviposition period varied from 4 to 23 with differences between post-oviposition periods significant. The shorter differences between generation period $(5.85 \pm 0.20$ days $)$ was observed in $2^{\text {nd }}$ generation at 32 . $9^{\circ} \mathrm{C}$ and $50.0 \% \mathrm{R}$. H., follow $(11.3 \pm 0.58$ days $)$ in $1^{\text {st }}$ generation at $35.0^{\circ} \mathrm{C}$ and $50.4 \%$ R. H..and the longer period (17.0 \pm 0.60 days) occurred in the $3^{\text {rd }}$ generation at $26.7^{\circ} \mathrm{C}$ and $49.9 \%$ R. H

Results in Table (3) also showed that the oviposition period was greatly influenced by the prevailing laboratory temperature. The preoviposition,oviposition and post-oviposition periods were positively affected Similar results for oviposition periods and fecundity were reported by Bodenheimer (1951) in Palestine, Ezz (1965) in Egypt ,Azab et al (1969) and Sharaf El-Den ,et al (2009) ) in Egypt.

\section{4-Female Longevity:}

Longevity of females shown in Table (4) ranged between 66 and 255 days according to conditions with significant differences between the three annual generations. The longest longevity averaged $200.0 \pm 8.54$ days at $27.75{ }^{\circ} \mathrm{C}$ and $49.4 \% \mathrm{R}$. $\mathrm{H}$. in $3^{\text {rd }}$ generation, while that in the $2^{\text {nd }}$ generation averaged $113.15 \pm 5.10$ days at $34.8^{\circ} \mathrm{C}$ and $50.1 \%$ R.H. and the shortest longevity averaged $82.95 \pm 3.08$ days at $33.8^{\circ} \mathrm{C}$ and $50.2 \%$ R.H. Therefore, longevity of females was negatively correlated with temperature contrary to the average number of eggs/female (fecundity). 
In this respect Schrader (1930) in Pennsylvania reported that the longevity of adult of I. purchasi lasted two or three months. Sharaf El-Den ,et al (2009) ) in Egypt reported that the longest longevity average occurred in first generation followed by that in the second generation. for $l$. seychellarum.

\section{5-Incubation period:}

Results given in Table (4) showed that this period ranged 3-12 days in the $1^{\text {st }}$ generation, $10-31$ days in the $2^{\text {nd }}$ one and $30-45$ days in the $3^{\text {rd }}$ generation with significant differences. However, the egg incubation period averages were $8.25 \pm 0.60$ days, $19.0 \pm 1.83$ days and $39.2 \pm 1.16$ in the $1^{\text {st }}$, $2^{\text {nd }}$ a and $3^{\text {rd }}$ generations, respectively, with temperatures averaged $34.1^{\circ} \mathrm{C}, 33.9^{\circ} \mathrm{C}$ and $27.6^{\circ} \mathrm{C}$ found that the respectively, .These results are in agreement with those obtained on I. purchasi by Kuwana (1922) in Japan, (21-27 days), Peng (1935) in China, (9- 27 days), Geier and Baggiolini (1950) in Switzerland, (36 days) Bodenheimer (1951) in Palestine (16-35 days), Monastero and Zaazmi (1959) in France, (15-30 days), Ezz (1965) in Egypt, found that the incubation period of $I$. aegyptiaca ranged between 4-17 days and Azab et al (1969) in Egypt pointed out that eggs of $I$. aegyptiaca hatch, 8.6 days at $29.7^{\circ} \mathrm{C}$ and 10 days at $24{ }^{\circ} \mathrm{C}$. Sharaf El-Den et al (2009) ) in Egypt found that the incubation period averages were nearly similar in both generations for $I$. seychellarum.

\section{6-Total life cycle}

In Table (4) results revealed that the life cycle was completed in 94167days in $1^{\text {st }}$ generation, $110-234$ days in the $2^{\text {nd }}$ generation and 207399days in the $3^{\text {rd }}$ generation. Temperature and $\mathrm{RH}$ had significant effect. The life cycle was longer ( $311.05 \pm 14.06$ days) at mean temp. $27.7^{\circ} \mathrm{C}$ with $50.4 \pm 0.49 \% \mathrm{RH}$. in $3^{\text {rd }}$ generation, $(147.0 \pm 10.40$ days $)$ was at mean temp. $33.6^{\circ} \mathrm{C}$. with $51.2 \pm 0.46 \% \mathrm{RH}$. in $2^{\text {nd }}$ generation and $(128.45 \pm 5.69)$ was at mean temp. $34.1^{\circ} \mathrm{C}$. with $50.3 \pm 0.39 \% R H$. in $1^{\text {st }}$ generation. In this respect, Kuwana (1922) in Japan, recorded four months for $I$. purchasi under favorable conditions to complete life cycle: Ramachandra and Cherian (1944) in Switzerland reported that the generation duration of $I$. purchasi varied according to temperature and lasted 43-240 days; Azab et al (1969) in Egypt recorded 105.4 days at $26.4^{\circ} \mathrm{C}$ and 87.2 days at $28.7^{\circ} \mathrm{C}$ for $I$. aegyptiaca Khalaf (1987) in Fars, found that the life cycle of $I$. purchasi lasted from 70 140 days; and Sharaf El-Den at el (2009) ) in Egypt reported that total life cycle completed in 217-376 days in first generation and 180-384 in that of the second generation for I. seychellarum.

\section{7-Generations}

Determination of the number of annual generations of M.hirsutus under laboratory conditions was conducted. Three overlapping generations could be reared in the lab. as shown in Table (5). 
Osman, Evon A.

4

996 
The $1^{\text {st }}$ generation lasted for about four months under mean tem. $31.5^{\circ} \mathrm{C}$ and $50.1 \% \mathrm{R}$. H. The average durations of nymphs, adult females and incubation periods (Tables 1 \& 4) were $37.25 \pm 0.91,82.95 \pm 3.08$ and $8.25 \pm 0.61$ days, respectively. Under mean lab. temp. $28.0^{\circ} \mathrm{C}$ and 51.0 $\%$ R. H., the $2^{\text {nd }}$ generation lasted for about 7-months .Under these conditions, nymphal, adult females and egg stages lasted $32.8 \pm 1.21$ , $113.15 \pm 5.10$ and $19.0 \pm 1.83$ days.respectively, and the $3^{\text {rd }}$ generation lasted for about 9 -months. The average durations of nymphs, adult females and incubation periods were $71.8 \pm 2.34,200.0 \pm 8.54$ and $39.2 \pm 1.16$ days respectively.

Generation duration depended on the prevailing temperature with negative correlation. The present results are in agreement with the findings of Azab et al (1969) and Aly (1980) in Egypt reporting two annual

generations for $I$. aegyptiaca and for I. seychellarum. Khalaf (1987) in Fars, found that $I$. purchasi has 4 generations year. and Sharaf ElDen et al (2009) ) in Egypt reported two annual generations for $I$. seychellarum

Table (5): First and last occurrence of different stages of $M$. hirsutus reared on potato sprouts during the three successive annual generations under laboratory conditions.

\begin{tabular}{|c|c|c|c|c|c|c|c|c|c|}
\hline \multirow{3}{*}{\multicolumn{2}{|c|}{ Generations }} & \multicolumn{8}{|c|}{ First and last occurrence of } \\
\hline & & \multicolumn{3}{|c|}{ Nymphal stage } & \multirow{2}{*}{$\begin{array}{c}\text { Adult } \\
\text { female }\end{array}$} & \multirow{2}{*}{ Egg stage } & \multirow{2}{*}{ Pre-pupa } & \multirow{2}{*}{ pupa } & \multirow{2}{*}{$\begin{array}{l}\text { Adult } \\
\text { male }\end{array}$} \\
\hline & & instar & $2^{\text {nd }}$ instar & $3^{\text {rd }}$ instar & & & & & \\
\hline \multirow{2}{*}{ First } & From & $12 / 5 / 2009$ & $28 / 5 / 2009$ & $12 / 6 / 2$ & $12 / 6 / 2009$ & $22 / 6 / 2009$ & & 19 & $8 / 7 / 200 s$ \\
\hline & To & $3 / 6 /$ & $14 /$ & $26 /$ & $24 /$ & & & & $21 /$ \\
\hline \multirow{2}{*}{ Second } & From & $1 / 7 /$ & & $25 /$ & & & & & \\
\hline & To & $2 / 8 / 2009$ & $15 / 8 /$ & $1 / 9 / 2$ & $7 / 1$ & & 31 & $9 / 9$ & $11 / 9 / 2009$ \\
\hline \multirow{2}{*}{ Third } & From & $23 / 8 / 2009$ & $5 / 9 / 2009$ & $20 / 9 / 2009$ & $17 / 1$ & $19 / 11 / 2009$ & $20 /$ & $4 / 10$ & $20 / 10$ \\
\hline & To & $8 / 11 / 2009$ & $29 / 11 / 2009$ & $6 / 1 / 2010$ & $10 / 8 / 2010$ & $26 / 7 / 2010$ & $26 / 12 / 2009$ & $14 / 2 / 2010$ & $14 / 2 / 2010$ \\
\hline
\end{tabular}

\section{REFERENCES}

Aly, A. G. (1980): Studies on palm trees insects belonging to super family Coccoidea in Egypt. Ph. D. thesis, Fac. of Agric., Al-Azhar Univ., 188 $\mathrm{pp}$

Azab, A. K.; Tawfik, M. F. S. and Ezz, A. I. (1969): Studies on Icerya aegyptiaca (Douglas) (Homoptera, Margarodidae). Bull. Soc. Entomol. d'Egypte,52:155-178.

Bodenheimer, F. C. (1951): Citrus entomology in the Middle East (472$488 \mathrm{pp}, \mathrm{W}$ Junk, the Hague, Netherland)

Chong, J.H., Roda, A.L., Mannion, C.M. (2008): Life history of the mealybug, Maconellicoccus hirsutus (Hemiptera: Pseudococcidae), at constant temperatures. Environmental Entomology, 37(2), 323-332.

Ezz, A. I. (1965): The morphology and biology of Icerya aegyptiaca Douglas. M. Sc. Thesis, Fac. Agric., Cairo Univ. 


\section{Osman, Evon A.}

Geier, P. and Baggiolini, M. (1950): Quelques observations sur la biologic de Icerya purchase Mask au Tessin (Homoptera, Margarodidae). Mitt. Schwiez. Ent. Ges, XXIII, (2): $104-1160$ (C.F. R.A.E., XLI: 323-1953).

Gonzalez-Gaona, E., Sanchez-Martinez, G., Zhang, A., Lozano-Gutierrez, J., Carmona-Sosa, F. (2010). Validation of two pheromonal compounds for pink hibiscus mealybug in Mexico. Agrociencia, 44(1), 65-73.IUCN SSC Invasive Species Specialist Group Page 7

Kairo, M.T.K., Pollard, D.D., Peterkin, B.V., \& Lopez, V.F. (2000). Biological control of the hibiscus mealybug, Maconellicoccus hirsutus Green (Hemiptera:Pseudococcidae) in the Caribbean. Integrated Pest Management Reviews, 5, 241- 254.

Khalaf, J. (1987): Biological control of Icerya purchasi in Fars. Entomol. et Phytopathol. Appliq. 54 (1-2): 47- 48.

Kuwana, I. (1922): Studies on Japanese Monophlebinae. Contribution II: The Genus Icerya (Japan). Dept. Agric. Econ., Imp. Quar. Sta., II: 43 pp. (C.F. R.A.E., XI: 29, 1923).

Monastero, S. and Zaazmi, V. (1959): Le cocciniglie degli agrumi in sicilia (Ceroplastes sinensis D., Pseudococcus citiri R and Icerya Purchasi Mask.) Bull. Ent. Agric. Palermo, III: 50-74 .

Peng, P. (1935): Biology of Icerya purchasi Mask. in Hwangyen (Homoptera, Coccidae). Bur. Ent. Heng chow, IV: 189-203. (C.F. R.A.E., XXIV: 480, 1936)

Ramachandra, R. A. O. and Cherian, M. C. (1944): The fluted scale, Icerya purchasi Mask. as a pest of wattle in south India, and its control by the biological methods. Madras. Agric. J., .XXXIII (3-5): 384-386

Ranjan, R. (2006). Economic impacts of the pink hibiscus mealybug in Florida and the United States. Stochastic Environmental Research and Risk Assessment, 20, 35 - 362.

Reddy, G.V.P., Muniappan, R., Cruz, Z.T., Naz, F., Bamba, J.P., and Tenorio, J. (2009). Present status of Maconellicoccus hirsutus (Hemiptera: Pseudococcidae) in the Mariana Islands and its control by two fortuitously introduced natural enemies Journal of Economic Entomology, 102(4), 1431-1439.

Schrader, S. H. (1930): Contribution to the life history of the ineryine coccids, with special reference to parthenogenesis and herm phroditism. Ann. Ent. Soc. Amer.,XXIII: 359-365

Sharaf El-Den ,A. A., El-Maasarawy S.A.S., Saad A.G.A . and Osman,E.A.(2009): Biological studies on The seychelles fluted scale mealy bug, Icerya seychellarum (Westwood)on seedlings of Mulberry (Mours alba L.) under laboratory conditions. Fayoum J. Agric. Res. \& Dev., Vol. 23 , No.2, July,2009 pp: 145-155.

Snedecore, G. W. (1970): Statistical methods applied to experiments in Agriculture and Biology. lowa State Press, U.S.A., 534 pp.

Ujjan, A.A.and Shahzad, S. (2007). Pathogenicity of Metarhizium anisopliae var acridum strains on pink hibiscus mealy bug (Maconellicoccus hirsutus) affecting cotton crop. Pakistan Journal of Botany, 39(3), 967973. 
دراسات بيولوجية على حشرة بق الهبسكس الاقيقي على درنـات البطاطس تحت الظروف المعليه إيفون عبداللة عثمان المبان معهر بحوث وقايه النباتات_مركز البحوث الزراعيه الدقى- جيزة مصر.

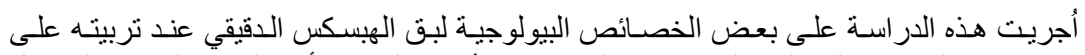

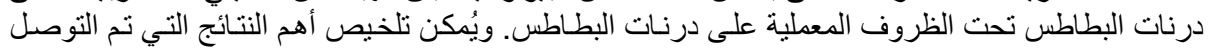

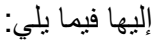

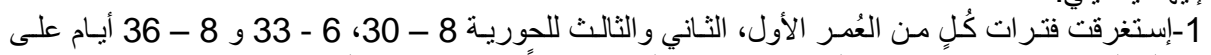

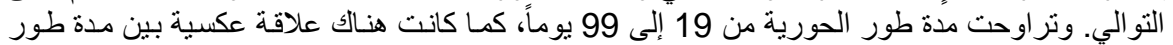

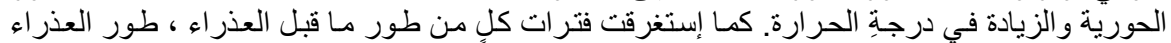

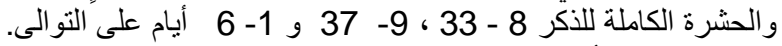

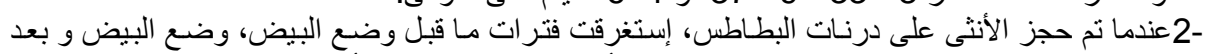

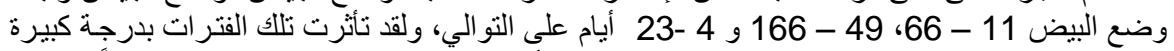

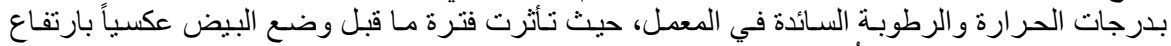

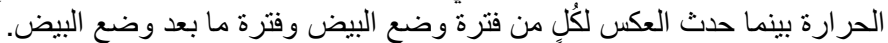

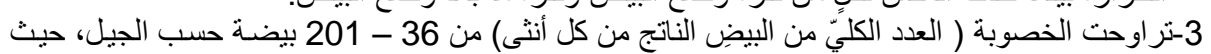

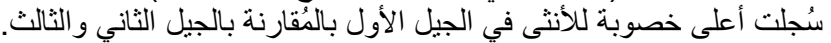

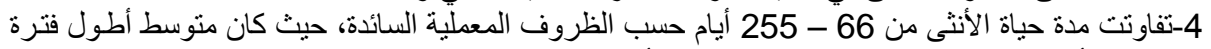

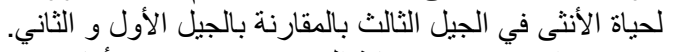

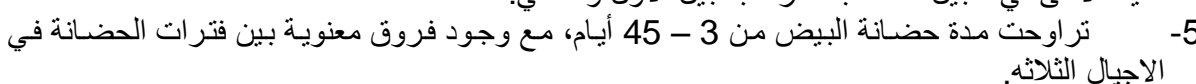

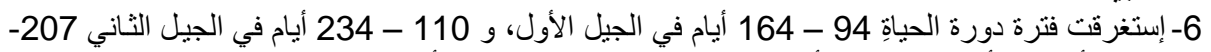

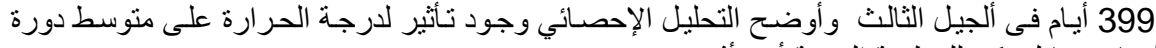

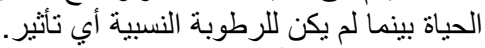

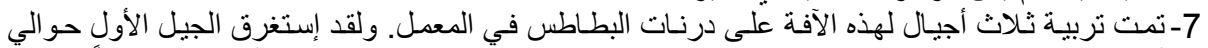
أربعة شهور ، بينما إستغرق الجيل الثاني حوالي سته شهور وإستغرق الجيل الثيل الثالث أحد عشر شهر أ.

كلية الزراعة - جامعة المنصورة معه بحوث وقاية النباتات
قام بتحكيم البحث

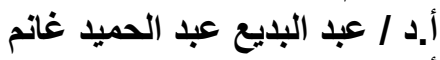

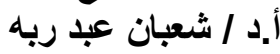


Osman, Evon A. 
Table (4): Female longevity, incubation period and total life cycle of $M$. hirsutus reared on potato sprouts during the three successive annual generations of under laboratory conditions.

\begin{tabular}{|c|c|c|c|c|c|c|c|c|c|c|c|c|c|c|c|}
\hline \multirow{3}{*}{ 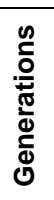 } & \multicolumn{5}{|c|}{ Female longevity } & \multicolumn{5}{|c|}{ Incubation period } & \multicolumn{5}{|c|}{ Total life cycle } \\
\hline & \multirow{2}{*}{$\begin{array}{c}\text { Range } \\
\text { (Mean } \pm \text { S.E) } \\
\text { (days) }\end{array}$} & \multirow{2}{*}{ 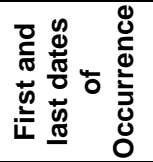 } & \multicolumn{3}{|c|}{$\begin{array}{c}\text { Laboratory } \\
\text { conditions averages }\end{array}$} & \multirow{2}{*}{$\begin{array}{c}\text { Range } \\
\text { (Mean } \pm \\
\text { S.E) } \\
\text { (days) }\end{array}$} & \multirow{2}{*}{ 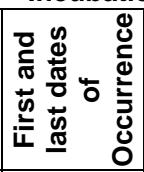 } & \multicolumn{3}{|c|}{\begin{tabular}{|c|} 
Laboratory \\
conditions averages \\
\end{tabular}} & \multirow{2}{*}{$\begin{array}{c}\text { Range } \\
\text { (Mean } \pm \\
\text { S.E) } \\
\text { (days) }\end{array}$} & \multirow{2}{*}{ 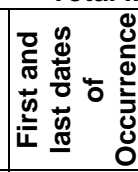 } & \multicolumn{3}{|c|}{$\begin{array}{c}\text { Laboratory conditions } \\
\text { averages }\end{array}$} \\
\hline & & & 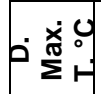 & $=\begin{array}{l}\dot{\Sigma} 0 \\
\dot{\Sigma} \\
z\end{array}$ & 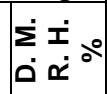 & & & 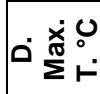 & 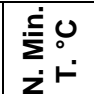 & 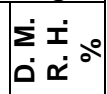 & & & 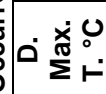 & $\begin{array}{l}\dot{S} 0 \\
\dot{\Sigma} 0 \\
z\end{array}$ & $\mid \begin{array}{l}\dot{\Sigma} \dot{x} \\
\dot{0} \dot{x}\end{array}$ \\
\hline$\stackrel{\bar{n}}{\vec{*}}$ & $\begin{array}{c}66-103 \\
(82.95 \pm \\
3.08) \\
\text { c } \\
\end{array}$ & $\begin{array}{c}12 / 6 \\
\text { till } \\
24 / 9\end{array}$ & $\mid \begin{array}{c}34.6 \pm \\
0.24\end{array}$ & $=\begin{array}{c}33.1 \pm \\
0.07\end{array}$ & $=\begin{array}{c}50.2 \pm \\
0.07\end{array}$ & $\begin{array}{c}3-12 \\
(8.25 \pm \\
0.61) \mathrm{C}\end{array}$ & $\begin{array}{c}22 / 6 \\
\text { till } \\
23 / 7\end{array}$ & $\begin{array}{c}34.6 \pm \\
0.61\end{array}$ & $\begin{array}{c}33.7 \pm \\
0.42\end{array}$ & $=\begin{array}{c}50.3 \pm \\
0.44\end{array}$ & $\begin{array}{c}94-164 \\
(128.45 \\
\pm \\
5.69) \mathbf{c} \\
\end{array}$ & $\begin{array}{c}12 / 5 \\
\text { till } \\
24 / 9\end{array}$ & $\begin{array}{c}35.4 \pm \\
0.21\end{array}$ & $\begin{array}{c}32.9 \pm \\
0.37\end{array}$ & $\begin{array}{c}50.3 \pm \\
0.39\end{array}$ \\
\hline 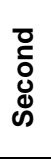 & $\begin{array}{c}81-158 \\
(113.15 \\
\pm \\
5.10) \\
\mathbf{b} \\
\end{array}$ & $\begin{array}{c}1 / 8 / 2009 \\
\text { till } \\
7 / 12 / 2010\end{array}$ & $\begin{array}{l}37.1 \pm \\
0.25\end{array}$ & $=\begin{array}{c}32.5 \pm \\
0.35\end{array}$ & $=\begin{array}{c}50.1 \pm \\
0.25\end{array}$ & $\begin{array}{c}10-31 \\
(19.0 \pm \\
1.83 \mathbf{b}\end{array}$ & $\begin{array}{c}14 / 8 \\
\text { till } \\
28 / 10\end{array}$ & $\begin{array}{c}34.7 \pm \\
0.11\end{array}$ & $\begin{array}{c}33.2 \pm \\
0.21\end{array}$ & $=\begin{array}{c}50.2 \pm \\
0.11\end{array}$ & $\begin{array}{c}110-234 \\
(147.0 \\
\pm \\
10.40) b\end{array}$ & $\begin{array}{c}1 / 7 \\
\text { till } \\
7 / 1 / 2010\end{array}$ & $\begin{array}{c}34.6 \pm \\
0.21\end{array}$ & $\begin{array}{c}32.7 \pm \\
0.39\end{array}$ & $\begin{array}{c}51.2 \pm \\
0.46\end{array}$ \\
\hline$\stackrel{\frac{0}{2}}{\frac{3}{1}}$ & $\begin{array}{c}125-255 \\
(200.0 \pm \\
8.54) \mathbf{a}\end{array}$ & $\begin{array}{c}17 / 10 / 2009 \\
\text { till } \\
10 / 8 / 2010\end{array}$ & $\mid \begin{array}{c}28.2 \pm \\
0.80\end{array}$ & $\begin{array}{c}27.3 \\
\pm \\
0.24\end{array}$ & $\begin{array}{c} \pm \\
49.4 \\
\pm \\
0.11\end{array}$ & $\begin{array}{l}30 / 45 \\
(39.2 \pm \\
1.16) \mathbf{a}\end{array}$ & $\begin{array}{c}19 / 11 / 2009 \\
\text { till } \\
29 / 3 / 2010\end{array}$ & $\begin{array}{c}28.2 \pm \\
0.12\end{array}$ & $\begin{array}{c}27.0 \pm \\
0.11\end{array}$ & $\begin{array}{c}49.2 \pm \\
0.21\end{array}$ & $\begin{array}{c}207-399 \\
(311.05 \pm \\
14.06) \mathbf{a}\end{array}$ & $\begin{array}{c}23 / 8 / 2009 \\
\text { till } \\
10 / 8 / 2010\end{array}$ & $\begin{array}{c}28.2 \pm \\
0.60\end{array}$ & $\begin{array}{c}27.2 \pm \\
0.40\end{array}$ & $\begin{array}{c}50.4 \pm \\
0.49\end{array}$ \\
\hline
\end{tabular}

Initial number used was 20

Means within a column followed by the different letter are significantly differ at $5 \%$. 


\section{Osman, Evon A}

1002 